\title{
Assessing the Reality of Special Education Centers Management in the Light of the Learning Organization Approach in the Provence of South Jordan
}

\author{
Dr. Mohammad Beirat (Corresponding author) \\ Assistance professor in special education \\ Al Hussein Bin Talal University / Faculty of Educational Sciences \\ Special Education Department \\ E-mail: mohammadbeirat@yahoo.com
}

Dr. Dima Mohammad Waswas

Associate Professor in Educational Management

Al Hussein Bin Talal University / Faculty of Educational Sciences

Curriculums and Teaching Department

Received: June 20, 2018 Accepted: July 31, 2018 Published: August 1, 2018

doi:10.5296/jse.v8i3.13269 URL: https://doi.org/10.5296/jse.v8i3.13269

\begin{abstract}
This study aimed at assessing the reality of special education centers management in the light of the learning organization approach through the perspective of its staff and recognizing the effect of some variables in the responses of the sample's members.

To realize this purpose, the descriptive approach was used through collecting and analyzing the data of this problem by using a scale to assess the reality of special education centers management after being developed by the two researchers and divided into four domains.

The sample consisted of (177) workers in special education centers: (52) administrators and (125) teachers. The results indicated that the private education centers management practices the domains of the learning organization with high estimation level as the first rank was taken by the domain of organizational structure flexibility and the domain of work teams. The third rank was occupied by the domain of knowledge management while the domain of sustained education took the fourth rank. The results also revealed the absence of statistically
\end{abstract}




\section{Macrothink}

significant effect for the responses of the sample's members due to the impact of gender variable, the presence of an effect of the work capacity for the work capacity variable in favor of the administrators, the presence of an effect for the years of experience variable in favor of the category of experience for more than 10 years and the presence of an effect of the academic qualification variable in favor of post graduate studies.

Keywords: Assessing of special education centers management, learning organization. 


\section{Introduction}

The learning organization is the organization of the twenty first century which is characterized by fast changes, multiple challenges, employing technology and communication, generating knowledge and attending human and intellectual capitals (Marsick \& Watkins, 2003). It is an organization which is run through a conscious and organized manner through focusing on the learning process as a core element in its values, objectives and daily operations. In other words, the concept of learning organization revolves around the organization's capacity to learn, acquire knowledge and quickly communicated to all administrative levels, as well as adopting the spirit of interaction, sharing and cooperation in work. To achieve that goal, the organization is to work continuously on removing all the organizational obstacles and barriers before the learning and sharing process (Bilkbeer, 2016). This is because of the accelerating changes witnessed by this age as a result of the communication and information revolution which made change the only constant thing imposing a new reality upon the organization compelling them to adopt new administrative concepts to adapt with these changes among which is the learning organization (Al-Taweel \& Ababneh, 2009).

The idea of learning organization was influenced by several concepts such as knowledge economy, organizational learning and organizational development. The starting point is one for all these ideas which is the presence of a sustained change. Institutions and societies lack stability and this keeps them in permanent transformation as no stable circumstances that last for life; thus individuals have to learn how to be leaning individuals and they have to reconstruct and develop their institutions to become learning organizations (Kezar, 2005).

The concept of learning organization moved to educational institutions from which are, special education centers, as a response to emerging challenges to be faced by sustained learning(Al-Hiary, Beirat, Tabbal, 2014) . And this requires dropping traditional administrative structures and practices, adopting modern administrative modules and patterns that cope with the present age, providing sustained learning opportunities, using them in achieving goals and connecting the workers performance to the organization performance as well as encouraging research, dialogue, participation and creativity (Al-Maliji, 2010).

Special education centers are considered one of the educational institutions that aim at educating and rehabilitating children with disabilities in their different categories, training them to acquire proper skills according to their capacities and abilities in accordance with informed plans and special programs to make them achieve the best level, and preparing them for public life and merging in society (Audeh, 2009). The subject of managing and organizing special education is deemed as one of the important and vital issues in the field of special education. It is not less important than other subjects due to its role in organizing, coordinating and guiding the efforts of the workers in special education towards achieving the expected goal as well as its role in coordinating with other entities related to special education programs (Al-Bablawi, 2012).

Special education centers rely on the efficiency of the administrative performance the mission of which is coordinating between all the parties of the educational process; performing the 
administrative functions represented in achieving the educational organization's objectives, adjusting its budget, identifying the responsibilities and duties of its workers and communicating and coordinating with parents and official and non-official entities related to the special education programs. In addition, the task of the management is to identify the terms and conditions of appointing teachers and the basics of admitting students organizing their rights, organizing day-to-day educational programs and specifying the educational goals and teaching methods (Al-Rousan, 2013).

(Al-Gharir, 2010) argues that the special education center management is a process that includes special activities and programs. Abd Al-Sabour (2010, 43) defines the special education centers management as "the management in charge of the special education programs in its different levels and stages in order to improve the educational outputs among the special needs category to the highest degrees their abilities allow and to achieve the quested educational goals stemming from the general objectives of the state".

Al-Jaraydeh (2012) states that special education is a national issue shared by governments, the official and local entities, and the whole society as the disabled person has the right to enjoy full care and complete rights due to the fact that all Jordanians are equal in rights and duties which puts grave responsibility on everybody's shoulders paving the way to fully merge them with society, and this makes prominent the great significance of the special education center management.

Since the special education centers are educational institutions, they are more in need of continuous teaching because the human being is their most important input and output. They perform to prepare individuals not just to live in the present which is characterized by severe change and haste in different life aspects but also to live in the future the circumstances of which have become more difficult to predict than ever (Ababneh, 2011). Thus, special education centers were obliged to incorporate the learning organization application within their centers.

Researchers disagreed on the definition of learning organization because of the variance among their intellectual schools. (Bleed, 2004, p1) defined it as "the organization the management of which continuously examines its experiences and transform them to knowledge available for all its human resources".

Abu Khder (2006, p 61) defined it as "the organization which develops its strategy, plans, structures and its working mechanisms and targets at enhancing the ability of its management to adapt its organized operations with changes and challenges and achieving its goals by supporting and encouraging sustained learning operations, self-development and exchanging experiences internally and externally".

(Moilanen, 2005) defined it as the organization which is run consciously through learning which is a key component of the values, vision and goals of the organization which works to find basics to facilitate, evaluate and develop learning.

(Murquardt, 2011, p 32) defined learning organization as "the organization that collectively and effectively learns and continuously works to improve its ability to manage and use 
knowledge, enable individuals through learning inside and outside the organization and use technology to organize learning and production".

(Brandt, 2003) stated that the learning organization has a promotive organizational structure open to the external environment, stimulates the will of challenge to achieve its goals and performs a continuous exchanging process with its external environment. (Cook, Staniforth \& Stewart, 1997) added that the learning organization works to link the individual performance to the organizational performance, invests in the human resources at all administrative levels with the maximum possible power, supports and promotes improvement operations in all aspects of the organization and attracts the best qualified human energy. This indicates that the transformation process from traditional organizations to learning organizations requires changing a set of methods summarized in the following:-

1- The organizational structure: following a flexible organizational structure allows the smooth flow of information and facilitates the free movement of individuals at work and forming the working teams that run their works freely without resorting to the center (Malkawi, 2007).

2- Transforming from the routine tasks to the empowerment tasks: This requires identifying the abilities of the individuals to be empowered, selecting them rationally, providing them with progress and development opportunities, training them and ensuring their stay to guarantee the success of the organization through working teams learned and capable of adapting and working (Ali, 2006).

3- Transforming from official control systems to participation: participation means adopting a strategy which all share in placing and executing it starting from senior management and ending at the lower levels where everybody shares their views, conceptions and activities able to develop the organization to achieve the expected objectives.

4- Transforming from feeding organization to adaptable culture: since the organization believes in learning, it works to find organizational values and culture that encourage learning and provide Incentives which forms a positive driveof the organization and its working individuals towards learning, adaptation, development and growth (Malkawi, 2007).

5- Transforming from the competition strategy to the cooperation strategy: the increase in the number of competitors made the cooperation strategy a solution that enables the organization to guarantee its survival and persistence through presenting opportunities of learning, cooperation and adaptation with the surrounding environment (Ali, 2006).

Moreover, the transformation from a traditional organization to a learning organization requires providing effective communication means among workers such as meetings and e-mails, enhancing dialog and research, and learning within small groups where the motivation of the individuals to work and development can be stimulated (Ababneh \& Al-Adwan, 2007).

\section{Previous studies}

The following is a presentation of the previous studies related to the issue of the learning 
organization.

The study of (Reece, 2004) aimed at identifying the possibility of the Australian University to become learning organizations. The study was applied on the Western Sydney University in Australia as a case study. The results showed a high level of applying the learning organization dimension in that university, and that Western Sydney University is a learning organization.

(Berrio, 2007) conducted a study that aimed at assessing Ohio University as a learning organization in the United States of America. The study used a questionnaire depending on Gordon model and included five dimensions of the learning organization which are (learning, individual, organization, technology and knowledge). The results revealed a high level in the learning organization dimensions the highest of which was for the dimension of organization.

The study of (Bersènaitè \& Šaparnis, 2007) about the assessment of the learning organization's dimensions aimed at identifying the employees' views about the applicability of the learning organization's dimensions and its governmental characteristics in the governmental organizations in Lithuania state. To achieve the objectives of the study, the researchers developed a questionnaire to collect information. The results revealed a high level of application of the learning organization's dimensions and indicated that the most prominent characteristics of the learning organization are flexibility, openness and change acceptance.

The study of Al-Nsour (2010) aimed at uncovering the effect of the learning organizations characteristics in achieving institutional excellence at the Ministry of Higher Education and Scientific Research of Jordan. The researcher prepared a questionnaire of (50) items distributed on the study sample consisted of (194) employees of the Ministry. The results pointed out that the ownership level of the organization's characteristics at the Ministry of Higher Education and Scientific Research of Jordan was medium and that the Ministry of Higher Education and Scientific Research of Jordan enjoys the characteristics of the learning organization.

The study of Abu Hashish (2011) aimed at identifying the availability of the learning organizations dimensions at Al-Aqsa University through the perspective of its workers, revealing the differences in the responses of the sample members according to the variables of (gender, specialization, years of service, work nature), presenting some recommendations to develop the university in the light of the learning organization concept and using the descriptive approach. The results of the study indicated that all the learning organizations dimensions at Al-Aqsa University are available in a medium degree.

The study of Al-Kbesi (2013) aimed at identifying the availability of the learning organization's dimensions in the private basic schools in Amman and their relationship with the administrative creativity of the managers through the perspective of teachers. The study sample consisted of (370) male and female teachers and used two instruments to collect data: the first to measure the learning organization's dimensions and the second to measure the level of administrative creativity among managers. The study indicated that the availability of 
the learning organization dimension in the private basic schools on Amman governorate was at a medium degree.

The results of the previous studies that handled the subject of the learning organization show that the concept of learning organization is applied in the educational institutions, weather in Arabic or foreign countries, at the level of the higher education institutions or the schools in a degree that ranged between high and medium and that the most prominent characteristic of the learning organization is flexibility.

\section{The problem and questions of the study}

Special education centers' managements are considered one of the important and vital subjects because of its role in organizing, coordinating and directing the employees' efforts working in the field of special education in order to achieve the educational objectives (Al-Rousan, 2013). Due to the educational and social role performed by the special education centers, it was important to apply in them the sustained learning. The success of special education centers depends on its ability to turn into learning organizations and since the management is the engine and guide of the institution towards achieving its objectives, so it becomes important to assess it in the light of the learning organization approach because the resulting modern administrative concepts of the information and communication revolution and knowledge explosion, made it necessary for the educational institutions to rebuild new structures characterized by the features of the learning organization which focus on the continuous support learning processes and the production of knowledge and exchanging it in an age where the basic advantage of competition has become quick learning and maximum utilization of knowledge (Qahwaji, 2014). The problem of the study can be determined by answering the following two questions:

1- What is the reality of the special education center management in the light of the learning organization approach in the province of South Jordan perceived by its workers?

2- Are there statistically significant differences at $(=0.05)$ in the responses of the sample members of the scale of assessing the reality of the special education centers in the light of the learning organization in the province of South Jordan due to the variables: gender, years of experience, work capacity, academic qualification and type of institution?

\section{Objectives of the study}

The present study is seeking to realize the following objectives:

- Assessing the reality of the special education center management in the light of the learning organization approach in the province of South Jordan through the perspective of its workers.

- Identifying the effect of the variables: gender, years of experience, occupation, academic qualification and type of institution in the responses of the sample members to the tool of assessing the reality of the special education centers in the light of the learning organization in the province of South Jordan. 


\section{Importance of the study}

The importance of the current study is determined by the following aspects:

- The study addresses a greatly significant administrative subject described by modernity namely the learning organization.

- The study tool is applied in the private education centers in the province of South Jordan which are of the educational institutions that provide services to the disabled category, the results of which will hopefully positively affect the management of those centers.

- The scarcity of studies about the learning organization and its applications in the private education centers makes this study as an additive to the educational literature.

- Hopefully, the results and recommendations of this study will affect the decision makers in the educational institutions to incorporate the concept of the learning organization and its applications in the special education centers.

- The researchers are hoped to benefit in the educational and administrative domain from the developing the scale of assessing the special education centers management.

\section{Limits and limitations of the study}

The study limits are as follows:

The chronological limit: The study tool was applied during the first academic semester of 2017/2018.

The special limit: the study tool was applied over the workers in the special education centers in the province of South Jordan.

The objective limitation: it is represented by the nature of the sample on which the study was applied. The tools that have been used in this study are: the scale of assessing the reality of special education centers' management in the light of the learning organization approach after verifying the coefficients of validity and reliability for each and the concluded results and the responsiveness of the study sample's members.

\section{Procedural definitions}

Following is a procedural definition for the main terminology in this study:

Assessing the special education centers: is judging the availability of the learning organization's domains represented in organizational structure flexibility, knowledge management, sustained learning and the working teams at the special education centers managements.

Special education centers: are the institutions joined by the disabled people to receive educational and social services in the province of South Jordan.

Learning organization: the special education centers where workers communicate to learn new material in the field of special education and apply what they lean in improving the 
performance quality and the centers' output. Four main domains were identified for the learning organization, which are: flexibility of the organizational structure, knowledge management, sustained learning and work teams.

\section{Method and procedures}

Following is a description of the study's methodology and procedures, the study population and sample, the study tool and the procedures used to verify the validity and reliability of the tool and the used statistical treatment.

\subsection{Study methodology}

In this study the descriptive approach was used which is the one that depends on studying the phenomenon as existed in reality and cares for describing it accurately. It is qualitatively expressed by showing its characteristics and quantitatively by giving it a digital description through figures and tables that explain the sum and size of this phenomenon and its correlation degree with other phenomena. This approach was adopted due to its appropriation to the nature of the study in terms of its objectives and the collection and analyzation of data.

\subsection{Study population and sample}

The study population consists of all the workers in the centers counting (250) workers in the special education centers in the province of South Jordan with the functional capacity of administrators and teachers. Those centers are distributed on Ma'an governorate with (9) centers, Al-Karak governorate with (19) centers, Al-Tafilah governorate with (5) centers, Aqaba governorate with (9) centers, where by the total number of centers was (42) centers. The number of the centers' managers was (52) and the number of teachers was (198) according to the statistics of the higher council of the disabled people for the year 2017 .

The study sample consisted of (177) workers in the special education centers distributed over (52) administrators; of which are (42) center managers, (10) department head and (125) teachers where (73) incomplete tools were excluded from the study population. Table (1) clarifies the distribution of the study sample members according to the demographic variables 


\section{Macrothink}

Table 1. the distribution of the study sample members according to the demographic variables

\begin{tabular}{|c|c|c|c|}
\hline & Categories & Repetition & Percentage \\
\hline \multirow[t]{2}{*}{ Gender } & Male & 37 & 20.9 \\
\hline & Female & 140 & 79.1 \\
\hline \multirow[t]{3}{*}{ Years of experience } & Less than 5 years & 104 & 58.8 \\
\hline & 5 to 10 years & 30 & 16.9 \\
\hline & Over 10 years & 43 & 24.3 \\
\hline \multirow[t]{2}{*}{ Occupation } & $\begin{array}{l}\text { Administrators (manager, department } \\
\text { head) }\end{array}$ & 52 & 29.4 \\
\hline & Teacher & 125 & 70.6 \\
\hline \multirow{3}{*}{$\begin{array}{l}\text { Academic } \\
\text { qualification }\end{array}$} & Diploma & 77 & 43.5 \\
\hline & Bachelor Degree & 87 & 49.2 \\
\hline & Post-graduate studies & 13 & 7.3 \\
\hline \multirow[t]{3}{*}{ Type of institution } & Governmental & 43 & 24.3 \\
\hline & Private & 56 & 31.6 \\
\hline & Voluntary & 78 & 44.1 \\
\hline \multicolumn{2}{|r|}{ Total } & 177 & 100.0 \\
\hline
\end{tabular}

Table (1) shows the following:

1. The number of females in the study sample was (140) with a percentage of $(79.1 \%)$ while the number of males was (37) with the percentage of (20.9\%).

2. The highest distribution percentage of the sample members according to the variable of the years of experience was for the less than 5 years of experience which reached at $(58.8 \%)$.

3. The highest distribution percentage of the sample members according to the variable of occupation was for the variable of teacher which reached at $(70.6 \%)$.

4. The highest distribution percentage of the sample members according to the variable of academic qualification was for the bachelor degree which reached at (49.2\%).

5. The highest distribution percentage of the sample members according to the variable of type of institution was for the variable of voluntary which reached at (44.1\%). 


\subsection{Study tool}

In order to achieve the objectives of the study the two researchers developed a scale which included two parts: the first was related to the demographic variables of the responders (gender, years of experience, occupation, academic qualification, the type of institution); the second included a scale of assessing the reality of special education center management in the light of the learning organization approach in the province of South Jordan and was divided into four domains: the first domain was the flexibility of the organizational structure with (12) items, the second domain was knowledge management with (10) items, the third domain was the sustained learning with (8) items and the fourth domain was the working teams with (8) items. Said items were developed by referring to the previous studies such as the study of Abu Hashish (2011), the study of Al-Kubaisi (2013) and the study of AL-Nsour (2010).

\subsection{Correcting the tool}

Likert scale quintet was adopted to correct the study tool by giving each item one degree of its five degrees (strongly agree, agree, neutral, disagree, strongly disagree) which are represented digitally by $(5,4,3,2,1)$ respectively. The following scale was adopted for the analyzation of results (Mneizel, Al-Aetum, 2010).

Low from 1.00 to 2.33

Medium from 2.34 to 3.67

High from 3.68 to 5.00

The scale was calculated by using the following equation:

The maximum degree of the scale (5) - The minimum degree of the scale (1) = 1.33

Number of required categories (3)

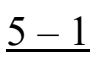

3

The result of (1.33) was added to the end of each category.

\subsection{Validity of the study tool}

The validity of the tool was verified by using the validity of arbitrators by offering it to (12) arbitrators specialized in the subject of the study in the Jordanian universities to present their opinion in each of the items located in the scale and in each dimension to which the item belongs and then coining each item in terms of the language and domain to which it belongs. An agreement standard with a percentage of $(90 \%)$ of arbitrators for each item was adopted, as for the items that were agreed upon with $(90 \%)$ of the arbitrators were kept.

\subsection{Reliability of the study tool}

To verify the reliability of the study tool test -retest approach was used by applying the scale 


\section{Al Macrothink}

and reapplying it two weeks later on a group of forty workers exterior to the study sample. Pearson correlation coefficient was calculated among their assessment in the two tests.

The reliability coefficient was also calculated by following the internal consistency approach according to Cronbach's Alpha equation. Table (2) shows the internal consistency coefficient according to Cronbach's Alpha equation and the test-retest reliability of the domains and the tool as a whole where those values were considered appropriate to the purposes of the study.

Table 2. internal consistency coefficient Cronbach's Alpha and the test-retest reliability of the domains and the total score

\begin{tabular}{|l|c|c|}
\hline Domain & Test-retest reliability & Internal consistency \\
\hline Flexibility of the organizational structure & 0.88 & 0.84 \\
\hline Knowledge management & 0.92 & 0.87 \\
\hline Sustained learning & 0.91 & 0.89 \\
\hline Team work & 0.89 & 0.91 \\
\hline Total & $\mathbf{0 . 9 2}$ & $\mathbf{0 . 9 4}$ \\
\hline
\end{tabular}

This part offers the results of the study which aims at assessing the reality of special education centers management in the light of the learning organization approach through the perspective of its workers. The following is a presentation of the results according to the questions of the study.

\section{Results and discussion}

\subsection{The results related to the first question}

1- First question: what is the reality of the special education centers in the light of the learning organization approach in the province of South Jordan through the perspective of its workers?

To answer this question the arithmetic mean and standard deviation were extracted for the domains of the reality of the special education center management in the light of the learning organization approach through the perspective of its workers as shown in table (3). 


\section{Mll Macrothink}

Table 3. Arithmetic mean and standard deviation for the domains of the reality of the special education center management in the light of the learning organization approach in the province of South Jordan in descending order according to the arithmetic means

\begin{tabular}{|l|l|l|l|l|}
\hline Rank & Domain & mean & $\begin{array}{l}\text { Standard } \\
\text { deviation }\end{array}$ & $\begin{array}{l}\text { Assessment } \\
\text { level }\end{array}$ \\
\hline $\mathbf{1}$ & $\begin{array}{l}\text { Flexibility of the } \\
\text { organizational } \\
\text { structure }\end{array}$ & 4.04 & 0.482 & High \\
\hline $\mathbf{3}$ & Teams work & 4.04 & 0.611 & High \\
\hline $\mathbf{3}$ & $\begin{array}{l}\text { Knowledge } \\
\text { management }\end{array}$ & 3.94 & 0.635 & High \\
\hline Total score & $\begin{array}{l}\text { Sustained } \\
\text { learning }\end{array}$ & 3.90 & 0.663 & High \\
\hline
\end{tabular}

Table (3) shows that the arithmetic means range between $(3.90-4.04)$, where the flexibility of the organizational structure and teams work occupied the first rank with the highest arithmetic mean of (4.04), whereas sustained learning occupied the last rank with an arithmetic mean of (3.90). the arithmetic mean of the tool as a whole was (3.98).

From the results of table (3) we see that the special education centers management has applied the domains of the learning organization in the province of South Jordan with a high level. this indicates that the special education centers in the province of South Jordan are learning organizations characterized by flexible organizational structures, team work spirit, and have the requirements of knowledge management and sustained learning.

Arithmetic means and standard deviations of the study sample members' assessments for the items of each domain separately, were calculated and the results were as follows:

9.1.1. First domain: the flexibility of the organizational structure

Table 4. Arithmetic means and standard deviations for the items of the domain of organizational structure flexibility in descending order according to the arithmetic means

\begin{tabular}{|c|c|c|r|r|c|}
\hline Rank & No. & \multicolumn{1}{c|}{ Items } & mean & $\begin{array}{c}\text { Standard } \\
\text { deviation }\end{array}$ & $\begin{array}{c}\text { Assessment } \\
\text { level }\end{array}$ \\
\hline 1 & 5 & $\begin{array}{l}\text { The communication channels are open } \\
\text { between the management and the works } \\
\text { of the center }\end{array}$ & 4.30 & 0.580 & High \\
\hline
\end{tabular}




\begin{tabular}{|c|c|c|c|c|c|}
\hline 2 & 2 & $\begin{array}{l}\text { The management explains the lines of } \\
\text { authority and responsibility in the } \\
\text { organizational structure's design }\end{array}$ & 4.28 & 0.759 & High \\
\hline 2 & 3 & $\begin{array}{l}\text { Organizational structure of the center is } \\
\text { characterized by flexibility (flexibility } \\
\text { means containing changes and dealing } \\
\text { with emergency circumstances without } \\
\text { creating a radical change in the main } \\
\text { features of the organizational structure). }\end{array}$ & 4.28 & 0.563 & High \\
\hline 4 & 7 & $\begin{array}{l}\text { The management directs instructions to } \\
\text { the workers through non-official } \\
\text { methods (issues oral instructions) }\end{array}$ & 4.25 & 0.579 & High \\
\hline 4 & 8 & $\begin{array}{l}\text { Orders and instructions flow from the } \\
\text { management to subordinates in the least } \\
\text { time and effort }\end{array}$ & 4.25 & 0.635 & High \\
\hline 6 & 9 & $\begin{array}{l}\text { The organizational structure is } \\
\text { distinguished by its ability to improve } \\
\text { the level of the center's performance }\end{array}$ & 4.21 & 0.639 & High \\
\hline 7 & 1 & $\begin{array}{l}\text { The management, in designing the } \\
\text { organizational structure, observes the } \\
\text { specialization of work }\end{array}$ & 4.18 & 0.806 & High \\
\hline 8 & 4 & $\begin{array}{l}\text { The organizational structure is } \\
\text { characterized by decentralization } \\
\text { (decentralization means giving some } \\
\text { powers by the management to the } \\
\text { workers to take decisions and solve } \\
\text { problems) }\end{array}$ & 3.97 & 1.019 & High \\
\hline 9 & 10 & $\begin{array}{l}\text { The organizational structure contributes } \\
\text { in unifying the efforts of workers in the } \\
\text { center to achieve the general objectives }\end{array}$ & 3.92 & 0.790 & High \\
\hline 10 & 6 & $\begin{array}{l}\text { The center's management follows a } \\
\text { controlling system over the workers } \\
\text { with a high level of flexibility }\end{array}$ & 3.81 & 0.962 & High \\
\hline 11 & 11 & $\begin{array}{l}\text { The center's management applies the } \\
\text { principle of continuous recycling of } \\
\text { tasks (recycling is the shift of the }\end{array}$ & 3.62 & 0.940 & \\
\hline
\end{tabular}




\begin{tabular}{|c|c|l|l|r|c|}
\hline & $\begin{array}{l}\text { employee in his work among different } \\
\text { divisions and units }\end{array}$ & & Medium \\
\hline 12 & 12 & $\begin{array}{l}\text { The management assigns some powers } \\
\text { to the workers to perform their work in } \\
\text { a method they deem relevant }\end{array}$ & 3.44 & 0.952 & Medium \\
\hline
\end{tabular}

Table (4) shows that the arithmetic means have ranged between $(3.44-4.30)$ where item (5) which states "The communication channels are open between the management and the works of the center" occupied the first rank with an arithmetic mean of (4.30), while item (12) which states "The management assigns some powers to the workers to perform their work in a method they deem relevant" took the last rank with an arithmetic mean of (3.44). The arithmetic mean of the organizational structure flexibility as a whole was (4.04).

In table (4), it is noticeable that all items have received a high assessment level except items (11 and 12) which received a medium assessment level, this indicates that the organizational structure in the special education centers is characterized by flexibility which is the predisposition to adaptation and encountering the internal and external changes without the need to create essential modifications, this is clear by the attempt of the management to open communication channels, the clarity of the authority and responsibility lines in the organizational structure, the communication of the management with the workers in official and non-official methods, and the decentralization of the organizational structure.

\subsubsection{Second domain: knowledge management}

Table 5. Arithmetic means and standard deviations of the items of knowledge management domain in a descending order according to the arithmetic means

\begin{tabular}{|c|c|l|c|c|c|}
\hline Rank & No. & \multicolumn{1}{c|}{ Items } & mean & $\begin{array}{c}\text { Standard } \\
\text { deviation }\end{array}$ & $\begin{array}{c}\text { Assessment } \\
\text { level }\end{array}$ \\
\hline 1 & 14 & $\begin{array}{l}\text { The center management facilities for its } \\
\text { workers obtaining information quickly }\end{array}$ & 4.23 & 0.772 & High \\
\hline 2 & 15 & $\begin{array}{l}\text { The centers' management has data base about } \\
\text { educational intellectual topic related to work }\end{array}$ & 4.21 & 0.671 & High \\
\hline 3 & 21 & $\begin{array}{l}\text { Center management opens various } \\
\text { communication channels with the workers to } \\
\text { transfer ideas and knowledge }\end{array}$ & 4.08 & 0.760 & High \\
\hline 4 & 19 & $\begin{array}{l}\text { The center organizes work data to facilitate } \\
\text { accessing it }\end{array}$ & 4.02 & 0.787 & High \\
\hline
\end{tabular}




\begin{tabular}{|c|c|c|c|c|c|}
\hline 5 & 13 & $\begin{array}{l}\text { The center management discloses the } \\
\text { information and decisions to the workers } \\
\text { transparently }\end{array}$ & 3.94 & 0.461 & High \\
\hline 6 & 20 & $\begin{array}{l}\text { The center management provides the workers } \\
\text { with different paper and electronic } \\
\text { information sources }\end{array}$ & 3.93 & 1.092 & High \\
\hline 7 & 22 & $\begin{array}{l}\text { The center management provides training and } \\
\text { participation for the workers to enhance their } \\
\text { knowledge }\end{array}$ & 3.80 & 0.989 & High \\
\hline 8 & 18 & $\begin{array}{l}\text { The center management provides internal } \\
\text { information network to access to the } \\
\text { specialized data bases }\end{array}$ & 3.75 & 1.043 & High \\
\hline 9 & 17 & $\begin{array}{l}\text { The center management applies a training } \\
\text { method by the most experienced colleagues }\end{array}$ & 3.72 & 1.010 & High \\
\hline 10 & 16 & $\begin{array}{l}\text { The center management distribute internal } \\
\text { bulletins to facilitate the access to new } \\
\text { knowledge }\end{array}$ & 3.69 & 0.898 & High \\
\hline \multicolumn{3}{|c|}{ Knowledge management } & 3.94 & 0.635 & High \\
\hline
\end{tabular}

Table (5) shows that the arithmetic means ranged between $(3.69-4.23)$ where item number (14) which states "The center management facilities for its workers obtaining information quickly" occupied the first rank with an arithmetic mean of (4.23) while item number (16) which states "The center management distribute internal bulletins to facilitate the access to new knowledge" took the last rank with an arithmetic mean of (3.69). The arithmetic mean of knowledge management as a whole was (3.94).

Table (5) points out that all the items of knowledge management were in a high assessment level. Knowledge management is the one that seeks to develop the individuals and groups working in the private education centers in the province of South Jordan through finding processes to generate, acquire, use and share knowledge in order to attain and develop knowledge and skills. This indicates that knowledge management is practiced in the special education centers by the management which appears through the easiness for employees to attain the required information, possessing data bases related to work and the easiness of communicating ideas and knowledge.

9.1.3. Third domain: sustained learning 
Table 6. Arithmetic means and standard deviations of the items of sustained learning domain in a descending order according to the arithmetic means

\begin{tabular}{|c|c|c|c|c|c|}
\hline Rank & No. & Items & mean & $\begin{array}{l}\text { Standard } \\
\text { deviation }\end{array}$ & $\begin{array}{c}\text { Assessment } \\
\text { level }\end{array}$ \\
\hline 1 & 24 & $\begin{array}{l}\text { The management discusses with the } \\
\text { workers the problems that face the } \\
\text { center to work on solving them }\end{array}$ & 4.18 & 0.565 & High \\
\hline 2 & 27 & $\begin{array}{l}\text { The center management gives the } \\
\text { workers a suitable time to receive } \\
\text { knowledge }\end{array}$ & 3.97 & 0.673 & High \\
\hline 3 & 23 & $\begin{array}{l}\text { The management helps the worker to } \\
\text { acquire learning }\end{array}$ & 3.96 & 0.800 & High \\
\hline 4 & 26 & $\begin{array}{l}\text { The center management prepares the } \\
\text { requirements for the workers to receive } \\
\text { learning }\end{array}$ & 3.94 & 0.921 & High \\
\hline 5 & 25 & $\begin{array}{l}\text { The center management defines the } \\
\text { educational needs for the workers } \\
\text { continuously }\end{array}$ & 3.88 & 0.636 & High \\
\hline 6 & 29 & $\begin{array}{l}\text { The management provides the workers } \\
\text { with enhancement against their } \\
\text { learning of new skills }\end{array}$ & 3.81 & 0.646 & High \\
\hline 6 & 30 & $\begin{array}{l}\text { The center management continuously } \\
\text { trains the workers by specialized } \\
\text { experts to make them achieve } \\
\text { empowerment }\end{array}$ & 3.81 & 1.268 & High \\
\hline 8 & 28 & $\begin{array}{l}\text { The management considers the } \\
\text { problems they face as opportunities for } \\
\text { learning }\end{array}$ & 3.63 & 0.969 & Medium \\
\hline \multicolumn{3}{|c|}{ Sustained learning } & 3.90 & 0.663 & High \\
\hline
\end{tabular}

Table (6) shows that the arithmetic means ranged between $(3.63-4.18)$ where item number (24) which states "The management discusses with the workers the problems that face the center to work on solving them" occupied the first rank with an arithmetic mean of (4.18) which item number (28) which states "The management considers the problems they face as opportunities for learning" took the last rank with an arithmetic mean of (3.63). The 
arithmetic mean of sustained learning as a whole was (3.90).

Table (6) indicates that most items of sustained learning are applied in the special education centers in the province of South Jordan in a high degree. Sustained learning targets at assisting the workers in the special education centers to confront different variables especially what is related to work to achieve continuous professional growth. This appears through the quest of the management to solve the problems that encounter work and the management assistance to the workers to receive knowledge and to prepare the requirements for this purpose in addition to identifying the training requirements for the workers, except for item number (28) which refers to the fact that the management considers the problems it faces as learning chances which received a medium assessment level. The two researchers explain this in that special education center management does not employ strategies to solve problems as a continuous learning method in solving problems.

\subsubsection{Fourth domain: work teams}


Table 7. Arithmetic means and standard deviations of the items of work teams' domain in a descending order according to the arithmetic means

\begin{tabular}{|c|c|c|c|c|c|}
\hline Rank & No. & Items & mean & $\begin{array}{l}\text { Standard } \\
\text { deviation }\end{array}$ & $\begin{array}{c}\text { Assessment } \\
\text { level }\end{array}$ \\
\hline 1 & 37 & $\begin{array}{l}\text { The management shows commitment to the } \\
\text { rules of collective work with the work teams }\end{array}$ & 4.29 & 0.692 & High \\
\hline 2 & 35 & $\begin{array}{l}\text { The management contributes in unifying the } \\
\text { work team members' efforts to achieve the } \\
\text { general objective of the center }\end{array}$ & 4.14 & 0.759 & High \\
\hline 3 & 36 & $\begin{array}{l}\text { The management cooperate with the work } \\
\text { teams to solve the problem that face the center }\end{array}$ & 4.08 & 0.753 & High \\
\hline 4 & 34 & $\begin{array}{l}\text { The center management provides all the } \\
\text { requirements needed by the work teams }\end{array}$ & 4.04 & 0.793 & High \\
\hline 5 & 31 & $\begin{array}{l}\text { The center management establishes different } \\
\text { teams to accomplish objectives and tasks }\end{array}$ & 3.98 & 0.603 & High \\
\hline 6 & 33 & $\begin{array}{l}\text { The objectives of the work teams are clearly } \\
\text { formed inside the center }\end{array}$ & 3.97 & 0.875 & High \\
\hline 7 & 32 & $\begin{array}{l}\text { The center management rewards the work } \\
\text { teams for realizing their accomplishments }\end{array}$ & 3.90 & 0.649 & High \\
\hline 8 & 38 & $\begin{array}{l}\text { The management follows up the work teams } \\
\text { while achieving their tasks }\end{array}$ & 3.89 & 1.044 & High \\
\hline \multicolumn{3}{|c|}{ Work teams } & 4.04 & 0.611 & High \\
\hline
\end{tabular}

Table (7) shows that the arithmetic means ranged between $(3.89-4.29)$ where item number (37) which states "The management shows commitment to the rules of collective work with the work teams" occupied the first rank with an arithmetic mean of (4.29), while item number (38) which states "The management follows up the work teams while achieving their tasks" took the last rank with an arithmetic mean of (3.89). The arithmetic mean for work teams as a whole was (4.04).

Table (7) indicates that all items related to the domain of work teams were of high assessment level. This indicates that the special education centers are seeking to achieve their works through the work teams and this is obvious by the management's commitment to the collective work rules and the management contribution in consolidating the efforts of the work teams' members to achieve the goals and the management's cooperation with the work teams to solve problems. 
9.2. The second question: Are there statistically significant differences at ( $\alpha=0.05)$ in the responses of the sample members of the scale of assessing the reality of the special education centers in the light of the learning organization in the province of South Jordan due to the variables: gender, years of experience, work capacity, academic qualification and type of institution?

To answer this question the arithmetic means and the standard deviations were extracted concerning the reality of the special education centers managements in the light of the learning organization approach through the perspective of its workers according to the variables of gender, years of experience, occupation, academic qualification and type of institution as shown in the following table.

Table 8. Arithmetic means and standard deviations for the reality of special education centers management in the light of the learning organization approach through the perspective of its workers according to the study's variables

\begin{tabular}{|l|l|c|c|c|}
\hline \multicolumn{2}{|c|}{ Categories } & mean & $\begin{array}{c}\text { Standard } \\
\text { deviation }\end{array}$ & No. \\
\hline \multirow{3}{*}{ Gender } & Male & 3.83 & 0.613 & 37 \\
\cline { 2 - 5 } & Female & 4.02 & 0.510 & 140 \\
\hline \multirow{5}{*}{ Years of experience } & Less than 5 years & 3.82 & 0.487 & 104 \\
\cline { 2 - 5 } & 5 to 10 years & 3.98 & 0.700 & 30 \\
\cline { 2 - 5 } & Over 10 years & 4.39 & 0.240 & 43 \\
\hline \multirow{3}{*}{ Occupation } & Administrators & 4.22 & 0.553 & 52 \\
\cline { 2 - 5 } & Teacher & 3.88 & 0.500 & 125 \\
\hline \multirow{5}{*}{ Academic qualification } & Diploma & 4.22 & 0.370 & 77 \\
\cline { 2 - 5 } & Bachelor Degree & 3.72 & 0.544 & 87 \\
\cline { 2 - 5 } & Post-graduate studies & 4.37 & 0.480 & 13 \\
\hline \multirow{5}{*}{ Type of institution } & Governmental & 3.41 & 0.351 & 43 \\
\cline { 2 - 5 } & Private & 4.21 & 0.525 & 56 \\
\cline { 2 - 5 } & Voluntary & 4.13 & 0.388 & 78 \\
\hline
\end{tabular}

Table (8) shows face variance in the arithmetic means and standard deviations of the reality of special education centers management in the light of the learning organization approach 


\section{Macrothink}

through the perspective of its workers in reference to the variables of gender, years of experience, occupation, academic qualification and type of institution. To show the significance of the statistical differences among the arithmetic means the five-way analysis of variance was used as shown in table (9).

Table 9. the five-way analysis for the effect of gender, years of experience, occupation, academic qualification and type of institution over the reality of special education centers management in the light of the learning organization approach in the province of South Jordan according to the perspective of its workers

\begin{tabular}{|l|c|c|c|c|c|}
\hline \multicolumn{1}{|c|}{$\begin{array}{c}\text { Source of } \\
\text { variance }\end{array}$} & $\begin{array}{c}\text { Sum of } \\
\text { squares }\end{array}$ & Df & $\begin{array}{c}\text { Mean of } \\
\text { squares }\end{array}$ & F value & $\begin{array}{c}\text { Statistical } \\
\text { significance }\end{array}$ \\
\hline \multicolumn{1}{|c|}{ Gender } & 0.235 & 1 & 0.235 & 1.711 & 0.193 \\
\hline experience
\end{tabular}

Table (9) shows the following:

- There are no statistically significant differences at $(\alpha=0.05)$ due to the effect of gender, where the $F$ value was (1.711) with a statistical significance of (0.193).

- The presence of statistically significant differences at $(\alpha=0.05)$ due to the effect of the years of experience where the $F$ value reached at (7.646) with a statistical significance of (0.001). To show the statistically significant binary differences among the arithmetic means the Post Hoc Comparison method of Scheffe was used as shown in table (9).

- There are statistically significant differences at $(\alpha=0.05)$ due to the effect of occupation where the $F$ value reached at (4.530) with a statistical significance of (0.035) and the differences were in favor of managers.

- There are statistically significant differences at $(\alpha=0.05)$ due to the effect of academic qualification, where the $F$ value reached at (5.898) with a statistical significance of $(0.003)$. To show the statistically significant binary differences among the arithmetic means the Post 
Hoc Comparison method of Scheffe was used as shown in table (9).

- There are statistically significant differences at $(\alpha=0.05)$ due to the type of institution where the $\mathrm{F}$ value reached at (22.828) with a statistical significance of $(0.000)$. To show the statistically significant binary differences among the arithmetic means the Post Hoc Comparison method of Scheffe was used as shown in table (9).

The two researchers explain the absence of statistically significant differences due to the effect of the variable of gender in that the Jordanian labor law has given equal rights and duties to male and females whether managers or teachers in the special education centers and also the workers of both genders where exposed to teaching and training in similar circumstances, thus it is logical not to find differences in practicing the organization's dimensions due to the variable of gender.

The two researchers also explain the presence of statistically significant differences due to the effect of the occupation variable in favor of the administrators because they shoulder the organizational, technical and supervisory duties in the special education centers. They are firstly responsible for the success of the special education centers and achieving their goals through seeking to incorporate modern administrative and educational applications such as the learning organization in the province of South Jordan which would create development at the level of the special education centers outcome.

Table 10. Post Hoc Comparison method of Scheffe for the effect of years of experience over the total score

\begin{tabular}{|l|c|c|l|l|}
\hline $\begin{array}{l}\text { Years of } \\
\text { experience }\end{array}$ & Mean & Less than 5 years & 5 to 10 years & Over 10 years \\
\hline Less than 5 years & 3.82 & & & \\
\hline 5 to 10 years & 3.98 & 0.16 & $* 0.41$ & \\
\hline Over 10 years & 4.39 & $* 0.57$ & $*$ & \\
\hline
\end{tabular}

* Statistically significant at $(\alpha=0.05)$.

Table (10) shows that there are statistically significant differences at $(\alpha=0.05)$ between the category of over 10 years of experience on the one hand and each of the category of less than five years of experience and the category of five to ten years of experience on the other hand. The differences came in favor of the category of over ten years of experience.

This can be explained in that these differences came in favor of the category of experience for over 10 years as the experience that has the greatest role in orienting the special education centers managers and teachers to adopt the learning organization's dimensions due to their clear effect over enhancing performance and achieving goals, as the more the experience increases the more knowledge and positive skills that participates in applying administrative approaches of positive effect on special education centers increases as well. 


\section{Macrothink}

Table 11. Post Hoc Comparison method of Scheffe for the effect of academic qualification over the total score

\begin{tabular}{|l|c|c|c|c|}
\hline $\begin{array}{l}\text { Academic } \\
\text { qualification }\end{array}$ & Mean & Diploma & $\begin{array}{c}\text { Bachelor } \\
\text { Degree }\end{array}$ & $\begin{array}{c}\text { Post-graduate } \\
\text { studies }\end{array}$ \\
\hline Diploma & 4.22 & & & \\
\hline $\begin{array}{l}\text { Bachelor } \\
\text { Degree }\end{array}$ & 3.72 & 0.16 & & \\
\hline $\begin{array}{l}\text { Post-graduate } \\
\text { studies }\end{array}$ & 4.37 & $* 0.57$ & $* 0.41$ & \\
\hline
\end{tabular}

*Statistically significant at $(\alpha=0.05)$

Table (11) shows that there are statistically significant differences at $(\alpha=0.05)$ between post-graduate studies on the one hand, and diploma and bachelor degree on the other hand. The differences came in favor of the post-graduate studies.

This can be explained in that the differences have come in favor the post-graduate studies category by the effect of the studies variables on the perspective of the administrators and teachers of the center who have post-graduate studies certificates to apply the dimensions of the learning organization in the province of South Jordan. This is a logical indicator and explains the effect of teaching in the knowledge, attitudes and practices of the workers in the special education centers towards applying the flexibility of the organizational structure, knowledge management and organizing work teams.

Table 12. Post Hoc Comparison method of Scheffe for the effect of the type of the institution over the total score

\begin{tabular}{|l|c|c|c|c|}
\hline $\begin{array}{l}\text { Type of } \\
\text { institution }\end{array}$ & Mean & Governmental & Private & Voluntary \\
\hline Governmental & 3.41 & & & \\
\hline Private & 4.21 & $* 0.81$ & & \\
\hline Voluntary & 4.13 & $* 0.72$ & 0.08 & \\
\hline
\end{tabular}

*Statistically significant at $(\alpha=0.05)$

Table (12) shows that there are statistically significant differences at $(\alpha=0.05)$ between the governmental institutions on the one hand, and the private and voluntary institutions on the other hand. The differences came in favor of the private and voluntary institutions.

This can be explained in that the differences have come in favor of the private and voluntary 
institutions because the private institutions receives support from different entities, this material and moral support contribute in creating development in the special education centers management and applying the dimensions of the learning organization in the province of South Jordan. In addition, the multiplicity of the supervising entities on the special education centers in both private and voluntary types requires the workers to enjoy the characteristics of the learning organization.

\section{Conclusions}

1- The special education center management practices the learning organization's domains with high assessment level, as the first rank was occupied by the domain of the organizational structure flexibility and work teams, the third rank was taken by knowledge management while the sustained learning took the fourth rank.

2- There are no statistically differences to the responses of the sample members due to the effect of the gender variable.

3- There are statistically significant differences to the responses of the sample members due to the effect of the occupation variable between the manager and teachers where the differences came in favor of the manager.

4- There are statistically significant differences to the responses of the sample members due to the effect of the years of experience variable between the category of more than 10 year experience on one side and each of the categories of less than 5 year experience and of 5 to 10 year experience. The differences came in favor of the category of more than 10 years experiences.

5- There are statistically significant differences to the responses of the sample members due to the academic qualification variable between the post-graduation studies category on the one hand and the categories of diploma and bachelor degree on the other hand, whereby the differences came in favor of the post graduate studies.

6- There are statistically significant differences to the responses of the sample members to the effect of the variable of the institution's type between the governmental institutions on one hand and the private and voluntary institutions on the other hand, where the differences came in favor of the private and voluntary institutions.

\section{Recommendations}

In the light of the aforementioned results, the two researchers recommend the following:

- Spreading the learning organization's culture among the administrators and teachers working at the private education centers through lectures and training courses.

- Founding sustained learning chances inside the special education centers and connecting work to teaching whereby the individuals get chances of learning while performing their work.

- The organizational culture inside the special education centers is to be characterized by 
inquiry, dialogue, feedback and discussion of different points of view.

- Holding lectures and seminars about establishing the application of the learning organization dimensions in the private education centers in particular and the educational institutions in general.

- Connecting the private education centers with each other for the sake of exchanging information and experience.

- Provoking an atmosphere of freedom in the work environment driving the workers to more accomplishment and presenting distinctive creative ideas.

- The special education centers are to adopt the team work method to improve the collective performance and to increase productivity.

- Employing the problem solving strategy in work as a method of working and learning in the special education centers.

- The private education centers managers are to assign many powers to the teachers and to train them to share the responsibility.

\section{References}

Ababneh, R., \& Al-Udwan, Y. (2007). The Factors that Affect Practicing Organizational Learning in the Jordanian Municipalities. The First Conference about Developing Human Resources in the Contemporary Organizations, Yarmouk University, Irbid, Jordan.

Ababneh, S. (2011). Public Schools Managers' Assessments of their Schools in Libya as Learning Organizations. Journal of Educational and Psychological Sciences, Bahrein, 12(4), 145-166.

Abd Al-Sabour, M. (2010). Adminstration and Supervision in Special Education, Dar Al-Zahra', Riyadh.

Abu Hashish, B. (2011). The Availability of the Learning Organization Dimension at Al-Aqsa University through the Perspective of Workers, Islamic University Journal, 19(2), 397-438.

Abu Khder, I. (2006). The Organizational Learning Management to Apply the Learning Organization Concept at the General Management Institute, unpublished $\mathrm{PhD}$ thesis, Faculty of Education, King Khalid University.

Al-Bablawi, I. (2012). Management, Supervision and Organization in Special Education, Dar Al-Zahra', Ryadh.

Al-Hiary, G., Beirat, M., \& Tabbal, S. (2014). Special Education Teachers in Jordan: Trends and Issues. Journal of Education and Practice, 5(39).

Al-Gharir., A. (2010). Special Education in Jordan, Dar Shurouq for Publishing, Amman, Jordan.

Ali, A. A.,S. (2006). Knowledge Management Approach, Dar Al-Masirah, Jordan. 
Al-Jaraydeh, D. (2012). Specal Education Centers Management in Jordan through the Perspective of its Workers (Problems and Solutions), unpublished PhD thesis, Yarmouk University.

Al-Kbesi, A. (2013). The Level of Availability of Learning Organization Dimensions in the Private Basic Schools in Amman Governorate and their Relationship with the Administrative Creativity of Managers from the Perspectives of Workers, unpublished master thesis, Middle East University, Amman, Jordan.

Al-Maliji, A. (2010). The Abundance of Knowledge and Organizational Learning are and Entrance for the Learning University in the Society of Knowledge. Taybah institution for publishing, Cairo.

Al-Nsour, A. (2010). The Effect of Learning Organization in Achieving the Institutional Excellence (Applied Study in Higher Education and Scientific Research Ministry in Jordan), unpublished master thesis, Middle East University, Amman, Jordan.

Al-Rousan, F. (2013). Issues and Problems in Special Education, Dar Al-Fikr, Amman.

Al-Taweel, H., \& Ababneh, S. (2009). The Learning Organization: Al-Mustaqbal School, Dar Wael, Amman.

Audeh, B., A. (2009). Supervision in Special Education, Dar Shurouq for Publishing, Jordan.

Berrio, A. A. (2007, August). Assessing the learning organization profile of Ohio State University extension using the systems-linked organizational model. In Management of Engineering and Technology, Portland International Center for(pp. 1542-1547). IEEE. https://doi.org/10.1109/PICMET.2007.4349477

Bersènaite, J., \& Šaparnis, G. (2007). Assessment of Features, State and Success Factors of a Learning Organisation: Aspect of Staff Opinions. Social Research, 1(9), 20-27

Bilkbeer, K. (2016). Realizing Organizational Distinction through the Learning Organization. New Economy Journal, 14(1).

Bleed ,R. (2004). A. learning Organization,http// www.Dist.Maricopa,ed

Brandt R. (2003). A school Culture that invites deep and Sustained Professional learning Will have a powerful impact on student achievement. Journal of staff Development, 2(1).

Cook, J. A., Staniforth, D., \& Stewart, J. (Eds.). (1997). The learning organization in the public services. Gower Publishing, Ltd. , http://www.ornazpn.com./dp/056607773

Kezar, A. (2005). What campuses need to know about organizational learning and the learning organization. New Directions for Higher Education, 2005(131), 7-22. https://doi.org/10.1002/he.183

Marquardt, M. J. (2011). Building the learning organization: Mastering the five elements for corporate learning. Hachette UK.

Marsick, V. J., \& Watkins, K. E. (2003). Demonstrating the value of an organization's 


\section{Macrothink}

Journal of Studies in Education

ISSN 2162-6952 2018, Vol. 8, No. 3

learning culture: the dimensions of the learning organization questionnaire. Advances in developing human resources, 5(2), 132-151. https://doi.org/10.1177/1523422303005002002

Milkawi, I. (2007). Knowledge Management, Practices and Concepts, Amman, Dar Al-warraq for Publishing.

Mneizel, A., \& Al-Atum, A. (2010). Research Methods in Psychological and Educational Sciences, Dar Thara' for Publishing, Amman, Jordan.

Moilanen, R. (2005). Diagnosing and measuring learning organizations. The Learning Organization, 12(1), 71-89. https://doi.org/10.1108/09696470510574278

Qahwaji, A. (2014). The Role of Learning Organization Dimensions in Enhancing the Workers Performance, Field Study in the Two Mobile Communication companies (MTN-Syriatel) in Damascus. Tishreen University Journal for Scientific Studies and Researchers, 36(6).

Reece, P. D. (2004). Universities as learning organizations: how can Australian universities become learning organizations? (Doctoral dissertation, Murdoch University). 